\title{
Production of Refractory Lining for Diesel Fired Rotary Furnace, from Locally Sourced Kaolin and Potter's Clay
}

\author{
Fatai Olufemi Aramide*, Saliu Ojo Seidu \\ Metallurgical and Materials Engineering Department, Federal University of Technology, Akure, Nigeria \\ Email: *foaramide@futa.edu.ng, seidu2@yahoo.co.uk
}

Received March 21, 2013; revised April 21, 2013; accepted April 30, 2013

Copyright (C) 2013 Fatai Olufemi Aramide, Saliu Ojo Seidu. This is an open access article distributed under the Creative Commons Attribution License, which permits unrestricted use, distribution, and reproduction in any medium, provided the original work is properly cited.

\begin{abstract}
This research was conducted to formulate a refractory lining recipe for lining diesel fired rotary furnace from locally sourced kaolin, using locally sourced potter's clay as binder. Six samples (A-F) of kaolin clay mined locally from Apata II area, Ondo road, in Ile-Ife, Nigeria, were roasted at $1200^{\circ} \mathrm{C}$ held for 8 hours, mixed with different percentages of raw kaolin and appropriately made into briquettes using potter's clay of good plasticity as binder. The samples were tested for various refractory properties. The result showed that sample mixes A (100\% chamotte), B ( $80 \%$ chamotte, $20 \%$ raw kaolin) and C (60\% chamotte, 40\% raw kaolin) are considered to have good properties. However, the optimum materialmix for the refractory bricks lining, with particular reference to the highest thermal shock resistance was found to be $80 \%$ chamotte mixed with $20 \%$ raw kaolin.
\end{abstract}

Keywords: Refractory; Chamotte; Raw Kaolin; Potter’s Clay

\section{Introduction}

Refractories are non-metallic materials capable of enduring high temperatures and suitable as construction materials for industrial furnaces. Their primary purpose is derived from their resistance to high temperatures, but they usually must withstand, in addition to one or more of the following destructive actions; abrasion, load, slag/ molten metal or salt [1].

Certain basic properties are required in any refractory, while others are specific for application. The most basic property is resistance to high temperatures and this is measured by standard pyrometric cone equivalent, PCE [2]. Refractories are critically important for the optimum performance of high temperature manufacturing processes among which are iron and steel making, glass and cement [3]. The availability and use of consistent, high quality refractories are very important for refractory users to maintain stable and efficient operations, and increase productivity. This is because refractories are inherently variable products; quality control is a constant requirement to insure consistent, high quality production. The importance of refractory in the global economy cannot be underestimated. According to Charles [4], the refractory

${ }^{*}$ Corresponding author. industry developed and flourished as a direct result of the need for heat resistant materials, to contain and control the thermal/chemical manufacturing processes of many industries. So the refractory industry has been, and continues to be an essential (although silent) partner for all traditional industries (iron, steel, cement, glass, ceramics, chemicals, petrochemicals, energy, etc.) which have been instrumental in the development and growth of the US (and world), especially since the mid-1800's e.g., westward migration, growth and modernization of agriculture, industrial revolution, growth of transportation, energy and fuel, infrastructure development, movement of materials/ commodities, military/defense needs, space exploration, modern electronics, and much more.

It must be emphasized that the goods produced by the steel industry, and all of the other manufacturing industries, would not be possible without refractories, which means that the economic impact and importance of refractories is MEGA-HUGE. The justification for this research endeavour is the fact that most industries in this country who make use of refractories in their production processes procured them from foreign Refractory Industries because those produced by local refractory industries "are not consistent in qualities/service properties" necessary for them to maintain stable and efficient operations, and increase productivity. 


\section{Materials and Method}

The materials used are kaolin and potter's clay of good plasticity as binder obtained from Ile-Ife and Iseyin in Nigeria respectively.

A predetermined quantity of the potter's clay was mixed with raw kaolin in the volume ratio of $4: 1$. The mixture was thoroughly mixed using sand muller and then sieved through $1000 \mu$-sieve size. Water was added to the sieved mix while mixing continued until uniform slurry was obtained. The resulting slurry was sieved through a $100 \mu-$ sieve, allowed to thicken in a container and subsequently decanted (clay slip) for use as binder. Thereafter a predetermined quantity of kaolin clay was calcined at a temperature of $1200^{\circ} \mathrm{C}$ in a furnace, held for 8 hours and allowed to cool in the furnace to obtain chamotte or fired kaolin. The chamotte was milled in a Rawwley Sussex grinder to an average particle size of about $500 \mu$. Some quantity of the dried raw kaolin was also ground, screened and similarly sieved to remove stone and other coarse particles. The chamotte and dried raw kaolin were added together at varied proportions and about $3.5 \mathrm{wt} \%$ of the prepared clay slip was also added as a binder to form six experimental mixes presented in Table 1 . The recipe was thoroughly mixed, rammed into a $50 \mathrm{~mm}$ diameter by 50 $\mathrm{mm}$ length cylindrical steel mould and subjected to pressure of 2 metric tones using hydraulic press. The procedure was repeated three times for each of the six experimental mixes presented in Table 1. All the prepared cylindrical specimens were dried in air for two days and then fired at $1200^{\circ} \mathrm{C}$, held at this temperature for about three hours and allowed to cool in the kiln to ambient temperature.

The apparent porosity, bulk density, and water absorption tests for each of the samples were carried out in accordance with ASTM C20-00 specification [5].

The percentage shrinkage and loss-on-ignition tests were carried out in accordance with ASTM C134-95 specification [6,7]. The cold crushing strength for each of the samples was evaluated in accordance with ASTM C133-97 specification [8], while the thermal shock resistance of the samples was evaluated in accordance with ASTM C1171-96 specification [9]. The chemical analysis of the materials from the samples were made and

Table 1. Material mix for the samples.

\begin{tabular}{ccc}
\hline \multirow{2}{*}{ Sample } & \multicolumn{2}{c}{ Proportion (\%) } \\
\cline { 2 - 3 } & Chamotte & Dried Raw Kaolin \\
\hline A & 100 & 0 \\
B & 80 & 20 \\
C & 60 & 40 \\
D & 40 & 60 \\
E & 20 & 80 \\
F & 0 & 100 \\
\hline
\end{tabular}

compared with that of the standard fireclay from literature [10].

\section{Results and Discussion}

Here, the results obtained from the experimental work are discussed in detail. Figures 1 to $\mathbf{6}$ illustrate the relationship in properties with respect to percentage chamotte content of the various samples. The chemical composition of the prepared samples made are presented in Table 2, while Table 3 showed the XRD result of the clay used as binder.

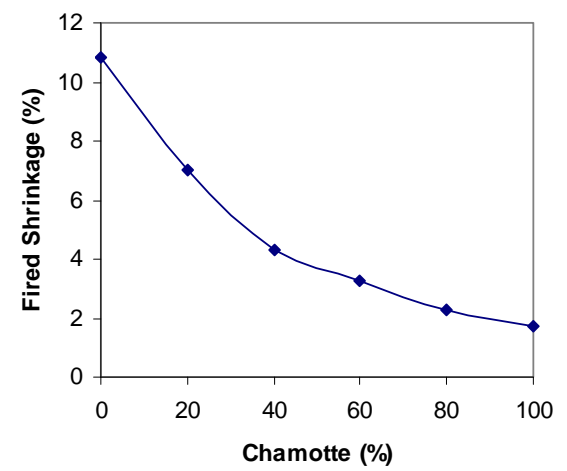

Figure 1. Effects of variation in chamotte content on the fired shrinkage of the samples.

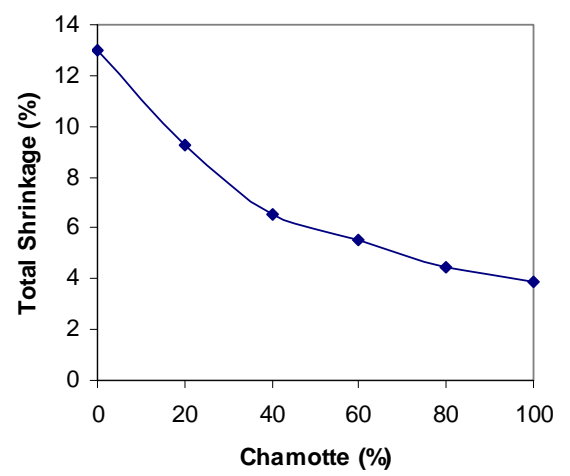

Figure 2. Effects of variation in chamotte content on the total shrinkage of the samples.

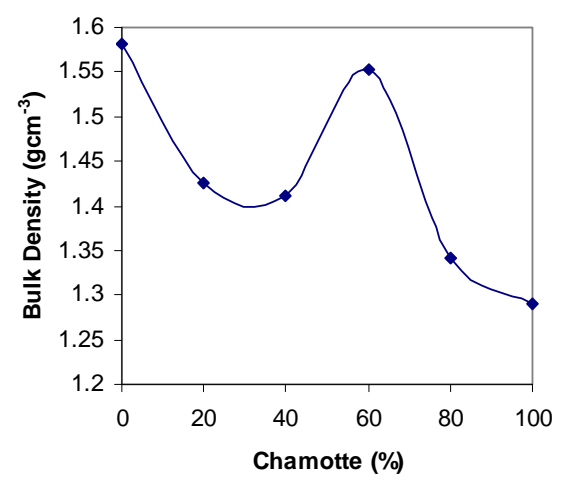

Figure 3. Effects of variation in chamotte content on the bulk density of the samples. 
Table 2. Chemical composition of the materials from which the test samples were made.

\begin{tabular}{|c|c|c|c|c|c|c|c|c|}
\hline sSample & 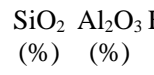 & $\begin{array}{c}\mathrm{Fe}_{2} \mathrm{O}_{3} \\
(\%)\end{array}$ & $\begin{array}{l}\mathrm{TiO}_{2} \\
(\%)\end{array}$ & $\begin{array}{l}\mathrm{CaO} \\
(\%)\end{array}$ & $\begin{array}{l}\mathrm{MgO} \\
(\%)\end{array}$ & $\begin{array}{l}\mathrm{Na}_{2} \mathrm{O} \\
(\%)\end{array}$ & $\begin{array}{l}\mathrm{K}_{2} \mathrm{O} \\
(\%)\end{array}$ & $\begin{array}{l}\text { LOI } \\
(\%)\end{array}$ \\
\hline Chamotte & 50.2044 .98 & 0.70 & 1.36 & 0.16 & 0.50 & 0.02 & 0.07 & - \\
\hline Raw Kaolin & 42.7839 .69 & 1.26 & 1.30 & 0.18 & 0.18 & 0.02 & 0.07 & 14.10 \\
\hline $\begin{array}{c}\text { Potter's Clay } \\
\text { (Binder) }\end{array}$ & 59.4235 .88 & 2.42 & 1.40 & 0.17 & 0.15 & 0.04 & 0.09 & 11.66 \\
\hline $\begin{array}{l}\text { Superduty } \\
\text { Fireclay }\end{array}$ & 57.0026 .70 & 1.60 & 1.10 & 0.20 & 0.70 & 0.10 & 2.00 & $12-15$ \\
\hline
\end{tabular}

Table 3. XRD result of the clay slip showing the quantity of different phases present.

\begin{tabular}{cc}
\hline Identified Phases & Weight (\%) \\
\hline Kaolinite & 39.71 \\
Microcline & 3 \\
Muscovite/lllite & 14.66 \\
Plagioclase Albite & 3.08 \\
Quartz & 39.55 \\
\hline
\end{tabular}

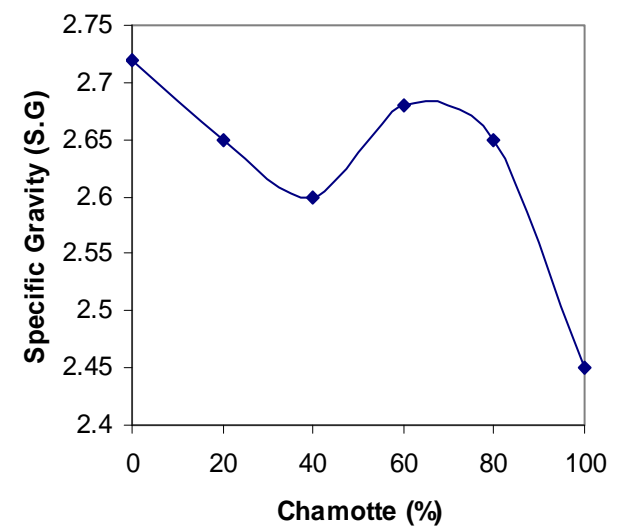

Figure 4. Effects of variation in chamotte content on the specific gravity of the samples.

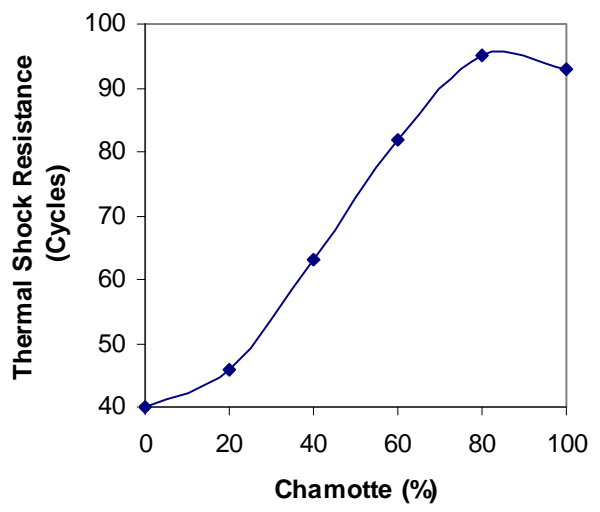

Figure 5. Effects of variation in chamotte content on the thermal shock resistance of the samples.
From Table 2, it observed that the kaolin clay contain various (low) percentages of oxides of iron, magnesium, calcium, titanium sodium and potassium; this is because kaolinite mineral is a product of the decomposition of feldspars and micas present in pegmatites and micaceous schist, its frequently found together with other minerals such as quarts, sulfides, feldspar, mica and iron and titanium oxides, among others [11].

From Tables 2, it could be observed that the iron, calcium, potassium and sodium oxides contents of both the raw kaolin clay, potter's clay used as binder and the fired kaolin clay (chamotte) were low. Perusing through Table 3 it could be observed that the microcline and plagioclase albite (feldspar) content of the binder clay were still low. Feldspar were mostly used as fluxing agent because of their high content of calcium, potassium and sodium oxides which favour liquid phase formation and densification at low temperature [12-17]. This low content of these fluxes will favour high temperatures applications.

Figures 1 and $\mathbf{2}$ show the effects of variation in chamotte content on the fired shrinkage of the samples and the effects of variation in chamotte content on the total shrinkage of the samples respectively.

Kaolin has the formula $\mathrm{Al}_{2} \mathrm{Si}_{2} \mathrm{O}_{5}(\mathrm{OH})_{4}$ or in a simpler form $\mathrm{Al}_{2} \mathrm{O}_{3} \cdot 2 \mathrm{SiO}_{2} \cdot 2 \mathrm{H}_{2} \mathrm{O}$. Due to its content of water of crystallization, it has a large firing shrinkage, this explains what is observable in Figures 1 and 2, a critical observation of these Figures reveals that the percentage shrinkage reduces in the test samples with increasing chamotte contents in the samples. Sample containing 100\% raw kaolin has the highest total firing shrinkage when fired at about $1200^{\circ} \mathrm{C}$, while sample with $100 \%$ fired kaolin has the lowest.

It can also be seen in Table 2 that there was no loss on ignition in the fired kaolin (chamotte) while the raw kaolin had $14.10 \%$ LOI. This is to be expected because, from the previous studies [5], when kaolin is heated, nothing note-worthy occurs in term of chemical or phase transformation until a temperature of about $450^{\circ} \mathrm{C}$ is reached. When the temperature is a little above $450^{\circ} \mathrm{C}$ there is about $14 \%$ weight loss and heat absorption of $170 \mathrm{cal} / \mathrm{gm}$.

Beyond this temperature, there is a breakdown of the kaolin structure, which is replaced by a material called meta-kaolin. This occurs at about $500^{\circ} \mathrm{C}$, when the combined water content in the clay is driven off and metakaolin is formed. With further heating, the meta-kaolin decomposes at about $970^{\circ} \mathrm{C}$ with a sharp evolution of heat to form a new crystal phase having a spinel structure similar to $\gamma-\mathrm{A}_{2} 0_{3}$. Above $1050^{\circ} \mathrm{C}$, this spinel structure gradually breaks down into mullite and cristobalite with an amorphous or glassy phase [5,18-22]. The grains of this phase grow coarser at $1200^{\circ} \mathrm{C}$ and form splice.

Figures $\mathbf{3}$ and $\mathbf{4}$ show the effects of variation in chamotte content on the bulk density of the samples and the effects 
of variation in chamotte content on the specific gravity of the samples respectively.

There is a loss of weight of about $14 \%$ at above $450^{\circ} \mathrm{C}$ when the raw kaolin transforms to meta-kaolin, and the growth of the grains at about $1200^{\circ} \mathrm{C}$ while forming splice [23-26]. Explain why the bulk density and specific gravity of the samples decrease with increasing chamotte content as shown in Figures 3 and 4, except for the sharp deviation from samples C and D (60\% and 40\% chamotte respectively). This confirms the fact that high temperature phases (allotropes) are always less dense than the lower temperature ones.

Figures $\mathbf{5}$ and $\mathbf{6}$ depict the relationships between the thermal shock resistance, cold crushing strength and the percentage chamotte content of the samples.

It is clearly seen that both properties increase in value with increase in the percentage chamotte content. The highest value for the thermal shock resistance being the sample with $80 \%$ chamotte and $20 \%$ raw kaolin.

Figures 7 and 8 show the relationship between these parameters and the apparent porosity of the samples.

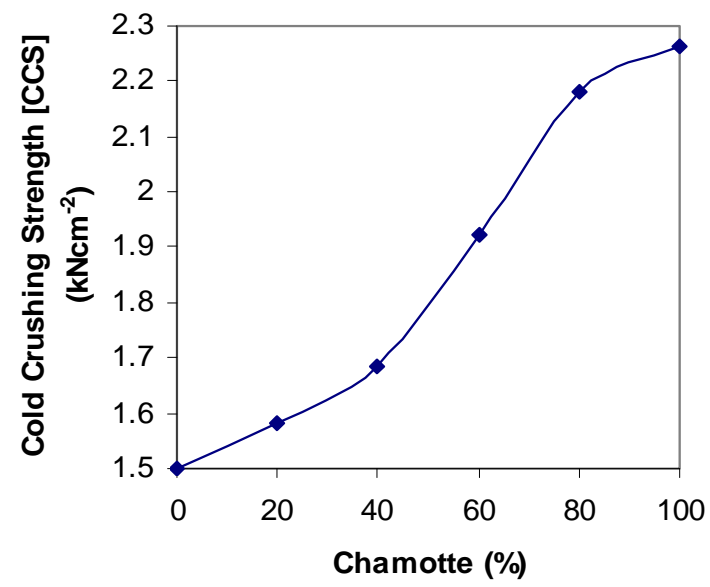

Figure 6. Effects of variation in chamotte content on the cold crushing strength of the samples.

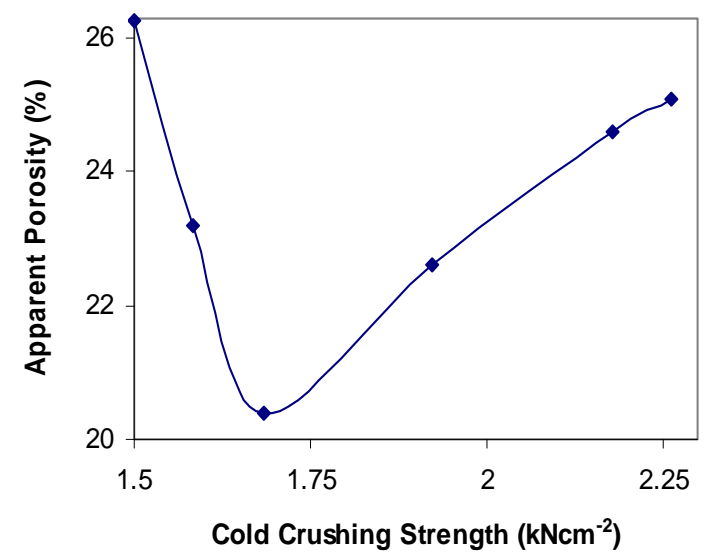

Figure 7. Relationship between apparent porosity and cold crushing strength of the samples.

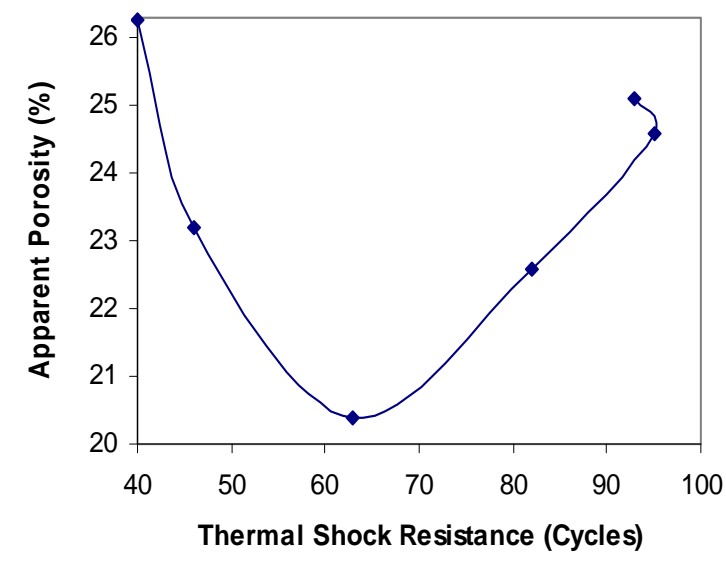

Figure 8. Relationship between apparent porosity and thermal shock resistance of the samples.

It can be observed that the porosity of the samples reduces from $26.28 \%$ to $20.40 \%$, and then increases to $25.10 \%$ as the thermal shock resistance increases. The better thermal shock resistance observed with increasing chamotte content from $40 \mathrm{vol} \%$ to $100 \mathrm{vol} \%$ as the porosity increases could be because the greater volume fraction of the internal pores in the samples structure arrests the propagation of cracks brought about by the thermal stresses the samples were subjected to. Also, samples with lower chamotte content have lower thermal shock resistance. This could be due to residual stresses setup in the structure of the samples as a result of the greater shrinkages resulting from the phase transformations of the raw kaolin [27]. All these may be due to the fact that the structure of brick has some influence on its load bearing capacity. A brick of high porosity will have lower load bearing capacity than one of the same material with lower porosity, since there is less material in the brick to carry the load in the former case. Porous bricks are lighter and therefore unlikely to carry heavy load [28].

\section{Conclusions}

An increase in the chamotte content increases the cold crushing strength and thermal shock resistance while it reduces the shrinkages, bulk densities and specific gravity of the test samples. However, increase in the chamotte content of the samples reduces the porosity to a certain threshold and then increases.

Samples with $100 \%$ chamotte, $80 \%$ chamotte, and $60 \%$ chamotte are considered to have good lining properties. However, with respect to the thermal shock resistance, sample with $80 \%$ chamotte and $20 \%$ raw kaolin is considered to be the optimum material-mix.

\section{Acknowledgements}

We are grateful to an anonymous referee for helpful comments. We also wish to thank Kim Humphreys for 
English editing. All errors are ours.

\section{REFERENCES}

[1] ASTM's Manual of Standard of Refractory Materials, "Proposed Glossary of Terms Relating to Refractories," 8th Edition, American Society for Testing Materials, Philadelphia, 1957.

[2] I. E. Campbell and E. M. Sherwood, "High Temperature Materials and Technology,” John Willey and Sons, Inc., New York, 1967.

[3] C. E. Semler, "Selected Factors That Contribute to Refractory Successes," Refractories Application and News, Vol. 10, No. 1, 2005, pp. 8-9.

[4] C. E. Semler, "Steel Industry-Status and Changes," Refractories Applications and News, Vol. 10, No. 2, 2005, pp. 7-9.

[5] I. W. M. Brown, K. J. D. Mackenzie, M. E. Bowden and R. H. Meinhold, "Outstanding Problems in the Kaolinite-Mullite Reaction Sequence Investigated with ${ }^{29} \mathrm{Si}$ and ${ }^{27}$ Al Solid-State Nuclear Magnetic Resonance: II, HighTemperature Transformations of Metakaolinite,” Journal of the American Ceramic Society, Vol. 68, No. 6, 1985, pp. 298-301. doi:10.1111/j.1151-2916.1985.tb15229.x

[6] American Society for Testing and Materials (ASTM), "Standard Test Methods for Size Dimensional Measurements and Bulk Density of Refractory Brick and Insulating Firebrick," ASTM Book of Standards, Vol. 15, No. 1, 1999, pp. 134-195

[7] American Society for Testing and Materials (ASTM), "Standard Test Methods for Apparent Porosity, Water Absorption, Specific Gravity and Bulk Density of Burned Refractory Brick and Shapes by Boiling Water," ASTM Book of Standards, Vol. 15, No. 1, 2000, pp. 20-100.

[8] American Society for Testing and Materials (ASTM), "Standard Test Methods for Cold Crushing Strength and Modulus of Rupture of Refractories," ASTM Book of Standards, Vol. 15, No. 1, 2003, pp. 133-197.

[9] American Society for Testing and Materials (ASTM), "Standard Test Methods for Quantitatively Measuring the Effect of Thermal Shock resistance and Thermal Cycling on Refractories,” ASTM Book of Standards, Vol. 15, No. 1, 2003, pp. 1171-1196.

[10] R. Morrell, "Handbook of Properties of Technical and Engineering Ceramics. Part I: An Introduction for the Engineer and Designer,” HMSO, London, 1985.

[11] J. A. Gonzalez, A. C. Carreras and M. del C. Ruiz, "Phase Transformation in Clays and Kaolins Produced bu Thermal Treatment in Chlorine and Air Atmospheres," Latin American Applied Research, Vol. 37, No. 2, 2007, pp. 133139.

[12] S. Ergul, M. Akyildiz and A. Karamanov, "Ceramic Material from Basaltic Tuffs,” Industrial Ceramics, Vol. 27, No. 2, 2007, pp. 89-94.

[13] W. D. Kingery, “Introduction to Ceramics,” John Wiley \& Sons, New York, 1976.
[14] J. S. Reed, "Principles of Ceramic Proceedings,” John Wiley \& Sons, New York, 1995.

[15] W. M. Carty and U. Senapati, "Porcelain-Raw Materials, Processing, Phase Evolution, and Mechanical Behavior," Journal of the American Ceramic Society, Vol. 81, No. 1, 1998, pp. 3-20. doi:10.1111/j.1151-2916.1998.tb02290.x

[16] T. Manfredini, G. Pellacani, M. Romagnoli and L. Pennisi, "Porcelainized Stoneware Tile," The Bulletin of the American Ceramic Society, Vol. 74, No. 5, 1995, pp. 76 79.

[17] J. Hlavac, "The Technology of Glass and Ceramics: An Introduction,” Elsevier, Amsterdam, 1983.

[18] G. W. Brindley and M. Nakahira, "Kinetics of Dehydroxylation of Kaolinite and Halloysite," Journal of the American Ceramic Society, Vol. 40, No. 10, 1957, pp. 346-350. doi:10.1111/j.1151-2916.1957.tb12549.x

[19] G. W. Brindley and M. Nakahira, "The Kaolinite-Mullite Reaction Series I: A Survey of Outstanding Problems," Journal of the American Ceramic Society, Vol. 42, No. 7, 1959, pp. 311-314. doi:10.1111/j.1151-2916.1959.tb14314.x

[20] G. W. Brindley and M. Nakahira, "The Kaolinite-Mullite Reaction Series II: Metakalin,” Journal of the American Ceramic Society, Vol. 42, No. 7, 1959, pp. 314-318. doi:10.1111/j.1151-2916.1959.tb14315.x

[21] G. W. Brindley and M. Nakahira, "The Kaolinite-Mullite Reaction Series III: The High-Temperature Phases,” Journal of the American Ceramic Society, Vol. 42, No. 7, 1959, pp. 319-323. doi:10.1111/j.1151-2916.1959.tb14316.x

[22] W. M. Carty and U. Senapati, "Porcelain-Raw Materials, Processing, Phase Evolution, and Mechanical Behavior," Journal of the American Ceramic Society, Vol. 81, No. 1, 1998, pp. 3-20. doi:10.1111/j.1151-2916.1998.tb02290.x

[23] G. Kakali, T. Perraki, S. Tsivilis and E. Badogiannis, "Thermal Treatment of Kaolin: The Effect of Mineralogy on the Pozzolanic Activity," Applied Clay Science, Vol. 20, No. 1-2, 2001, pp. 73-80. doi:10.1016/S0169-1317(01)00040-0

[24] M. Kaloumenou, E. Badogiannis, S. Tsivilis and G. Kakali, "Effect of the Kaolin Particle Size on the Pozzolanic Behavior of the Metakaolinite Produced," Journal of Thermal Analysis and Calorimetry, Vol. 56, No. 2, 1999, pp. 901-907. doi:10.1023/A:1010143214686

[25] R. E. Grim, "Clay Mineralogy, McGraw-Hill International, Series in the Earth Planetary Sciences,” McGraw-Hill, New York, 1968.

[26] C. S. Ross and P. F. Kerr, "The Kaolin Minerals,” Geological Survey Professional Paper (United States), Vol. 165, No. 1, 1931, pp. 151-180.

[27] L. Mattyasovszky-Zsolnay, "Mechanical Strength of Porcelain,” Journal of Materials Science, Vol. 40, No. 9, 1957, pp. 299-306.

[28] F. H. Norton, "Refractories,” 4th Edition, McGraw-Hill, New York, 1968. 